\title{
PERILAKU SOSIAL PENGGUNA NARKOTIKA DIKALANGAN REMAJA DESA PAI, KABUPATEN BIMA
}

\author{
Ramlin \\ Sakaria, Buchari Mengge \\ Program Magister Sosiologi Fakultas Ilmu Sosial Dan Ilmu Politik Universitas Hasanuddin Makassar \\ Email : ramlinhamzah91@Yahoo.Com
}

\begin{abstract}
Abstrak. Perilaku sosial yang dilakukan oleh anak-anak remaja telah mengganggu dan mempengaruhi orang lain, bahwa adanya perilaku penyimpangan sosial yang dilakukan oleh anak remaja,telah memberikan dampak yang negatif bagi masyarakat setempat dan juga keluarganya, karena tindakan yang dilakukan oleh mereka seperti pencurian, perkelahian dan juga penipuan dalam lingkungan masyarakat. Penelitian ini bertujuan, (1) untuk mengetahui gambaran perilaku social pengguna narkotika dikalangan remaja. (2) untuk mengetahui perilaku social pengguna narkotika berpengaruh terhadap keluarga dan masyarakat. Penelitian ini menggunakan pendekatan kualitatif dengan metode deskriptif kualitatif. Informan yang digunakan untuk memperoleh informasi dengan 10 informan. Metode pengumpulan data dilakukan dengan melalui wawancara, observasi dan dokumentasi. Teknik Penentuan Informan yaitu purposive sampling dan Snowball sampling. Kriteria informan dalam penelitian, mereka berdomisili di desa payi,remaja pengguna narkotika, keluarganya, mantan pengguna narkotika, tokoh masyarakat dan juga Kapolres dan BNN. Hasil Penelitian menunjukan bahwa, Adanya perilaku sosial pengguna narkotika dikalangan remaja, telah memberikan dampak yang negatif terhadap lingkungan masyarakat, karena perilaku mereka telah mengganggu dan merugikan orang banyak, sehingga yang terjadi sekarang, adanya pencurian, perkelahian dan juga penipuan, hal ini terjadi akibat efek dari narkotika yang remaja konsumsi.
\end{abstract}

Kata Kunci: Remaja, Narkotika, Perilaku Sosial.

\section{PENDAHULUAN}

Perdagangan narkotika dan obat terlarang merupakan suatu permasalahan yang dihadapi oleh banyak negara di dunia, namun dilain sisi bahwa Negara Indonesia juga mempunyai posisi strategis yakni berada di antara dua benua dan dua samudra. Keuntungan dari posisi geografis ini adalah semua negara di dunia mempunyai berbagai kepentingan terhadap Indonesia, karena merupakan salah satu rute perdagangan internasional ,namun dari kepentingan perdagangan dunia tersebut, tidak menutup kemungkinan hal itu bisa berpengaruh bagi negara indonesia dan juga masyarakat,karena di dalam perdagangan antar negara pasti akan terjadinya penyimpangan Penyalahgunaan narkotika.

Jurnal Ilmu Sosial dan Pendidikan
Remaja merupakan golongan yang rentan terhadap penyalahgunaan narkotika, karena selain memiliki sifat dinamis dan mereka juga memiliki sifat penasaran selalu ingin mencoba, maka mereka mudah terpengaruh dalam mengkonsumsi narkotika, akhirnya dampak yang ditimbulkan sebagai akibat dari perbuatan mereka,ternyata sangat merugikan dirinya sendiri, keluarganya, dan juga masyarakat sekitarnya.

Masalah penyalahgunaan narkotika ini bukan merupakan masalah yang kecil, tetapi merupakan masalah besar yang melanda siapa saja yang mencoba mendekatinya.

Sekarang permasalahan narkotika yang terjadi sangat mengkhawatirkan sehingga menjadi ancaman bagi masyarakat.Sehingga realitas yang terjadi sekarang dengan adanya 
Jurnal Ilmu Sosial dan Pendidikan

http://ejournal.mandalanursa.org/index.php/JISIP/index Terakreditasi Peringkat 5 (No. SK: 85/M/KPT/2020)

narkotika, telah menyebabkan rusaknya moralitas remaja, karena mereka terjerumus dalam mengkonsumsi narkotika, sehingga akhirnya mereka melakukan tindakan sosial yang tidak sesuai dengan norma-norma serta adat istiadat dan juga hukum yang berlaku dalam masyarakat. Selalu melakukan perbuatan seperti, perkelahian dan pencurian dan juga penipuan semakin merajalela di tengah kehidupan masyarakat.

Berdasarkan data yang diperoleh dari kapolsek kecamatan wera, kabupaten bima, bahwa kasus penyalahgunaan narkotika jenis sabu-sabu, peristiwa penyergapan terhadap 2 orang laki-laki pengguna dan sekaligus pengedar narkotika, karena memiliki 34 paket sabu-sabu, 2 orang pelaku berasal dari Desa Payi, kecamatan wera,kabupaten bima, yang ditangkap pada tanggal 27 januari 2018. Kemudian setelah itu terjadi lagi penangkapan yang dilakukan kapolsek kecamatan wera, terhadap 3 orang remaja yang sedang mengkonsumsi narkotika, karena mereka memiliki 2 paket narkotika jenis sabu-sabu, yang di tangkap pada tanggal 20 november 2018.

Perubahan perilaku sosial dikalangan remaja akhir-akhir ini telah merugikan dan meresahkan masyarakat banyak.hasil wawancara saya dengan masyarakat, ketika melihat perilaku remaja,mereka menyampaikan ada sebagaian remaja yang selalu membuat keributan di masyarakat. bahkan masyarakat sering kehilangan seperti kambing ,ayam dan juga yang lainnya. Bahwa dengan adanya perbuatan mereka ini sangat berpengaruh terhadap keluarga dan masyarakat sekitar.selama terjadinya perubahan perilaku anak-anak ini, ada beberapa aspek kehidupan masyarakat yang menjadi dampak akibat perbuatannya mereka seperti lingkungan sosial, ekonomi, agama. Akibatnya moralitasnya para remaja di desa payi, kecamatan wera. karena apa yang mereka lakukan membawa dampak yang negatif bagi kehidupan masyarakatnya.
Vol. 5. No. 1 Januari 2021

p-ISSN: 2598-9944 e- ISSN: 2656-6753
Berkaitan dengan permasalahan diatas suatu hal menarik bagi peneliti untuk mengkaji lebih mendalam.Sehingga penulis ingin meneliti sebagai syarat untuk mengajukan tugas akhir dalam bentuk Tesis Tentang:"Perilaku Sosial Pengguna Narkotika Dikalangan Remaja Desa Payi Kabupaten Bima (Studi Kasus, Desa Payi, Kecamatan Wera )".

\section{Rumusan Masalah}

Berdasarkan latar belakang yang telah dikemukakan di atas, dapat dirumuskan permasalahan penelitian sebagai berikut :

Bagaimana Gambaran perilaku sosial pengguna narkotika dikalangan remaja Kabupaten Bima?

\section{KAJIAN PUSTAKA}

\section{Perilaku sosial}

Menurut Max Weber, Perilaku sosial merupakan perilaku individu yang mempengaruhi aksi sosial dalam masyarakat yang kemudian menimbulkan masalah-masalah. Sehingga bahwa Perilaku sosial dberarti sikap dan tindakan, perilaku sosial berkaitan dengan norma sosial dan nilai-nilai kultural yang telah ditegakkan oleh masyarakat sebagaimana perilaku sosial bagi pengguna narkotika pada remaja itu merupakan perilaku menyimpang dalam masayarakat. Terjadinya tindakan menyimpang tersebut disebabkan oleh beberapa permasalahan individu yang berinteraksi dalam masyarakat. Perilaku menyimpang adalah perilaku pada warga masyarakat yang dianggap tidak sesuai kebiasaan, tata aturan, atau norma sosial yang berlaku ( Suyanto,2010 ).

\section{Pengaruh Perilaku Sosial Remaja Dalam Masyarakat}

\section{a) Pengaruh perilaku social}

Perilaku sosial remaja penyalahgunaan narkotika telah menimbulkan berbagai macam persoalan yang terjadi di tengah kehidupan masyarakat sekarang, hal ini bisa berpengaruh terhadap berbagai macam aspek yang ada dalam lingkungan masyarakat kita bisa sebutkan saja berdasarkan realiatas yang terjadi sekarang, yang pertama (1) aspek lingkungan sosial, (2) 
Jurnal Ilmu Sosial dan Pendidikan

http://ejournal.mandalanursa.org/index.php/JISIP/index

Terakreditasi Peringkat 5 (No. SK:

85/M/KPT/2020)

aspek budaya (3) agama, (4) aspek ekonomi. Sebagian aspek lingkungan sosial dampak dari pada perilaku remaja tersebut.

Dengan adanya perilaku sosial telah menimbulkan berbagai macam permasalahan yang terjadi dilingkungan sosial sekarang, kemunculan perilaku sosial ini telah merubah tatanan nilai sosial yang terkandung dalam masyarakat.Karena akhir-akhir ini berbagai macam persoalan dan permasalahan yang terjadi seperti pencurian, perkelahian, perkosaan, bahwa dengan adanya hal seperti itu sudah jelas membawa dampak yang buruk bagi masyarakat. Bahwa ada beberapa faktor-faktor menyebabkan terjadinya perilaku sosial remaja sehingga menggunakan narkotika sebagai berikut :

a. Faktor keluarga

1. Kurangnya perhatian dan pengawasan orang tua.

Dalam sebuah keluarga,mungkin karena faktor kesibukan,dan sebagainya, sehingga anak kurang mendapatkan perhatian dan pengawasan orang tua. Pada hakekatnya anak memerlukan perhatian orang tua agar dia dapat tumbuh dan berkembang secara wajar.oleh karena itu bila tidak ada perhatian orang tua, maka anak-anak mencari cara yang tidak benar dan cenderung berperilaku menyimpang yang tidak sesuai dengan norma-norma dan hukum yang berlaku dalam masyarakat.

2. Keluarga kurang harmonis.

Sebuah keluarga yang kurang harmonis, biasanya berdampak atau berpengaruh kurang baik kepada anaknya. Sehingga anaknya ingin mencari ketenangan diluar rumah, situasi dan kondisi demikian memberikan peluang bagi anak atau remaja terjebak dalam penyalahgunaan narkotika.

3. Pola pendidikan keluarga

Dalam sebuah keluarga pola pendidikan sangat penting, mungkin saja ada keluarga pola pendidikan mereka bersifat otoriter, maka dapat menimbulkan rasa ingin memberontak pada anak.Aturan-aturan yang
Vol. 5. No. 1 Januari 2021

p-ISSN: 2598-9944 e-ISSN: 2656-6753

serba melarang menyebabkan mereka menjadi tertekan.Kondisi demikian menimbulkan rasa perlawanan terhadap orang tua sehingga anak mencari kompensasi negatif dalam mengkonsumsi narkotika.

4. Komunikasi kurang terbuka pada anaknya.

Di dalam keluarga orang tua merupakan orang pertama dan utama bagi anak untuk mengepresikan perasaan, pikiran, dan masalah-masalah yang dihadapi mereka. Bila orangtua bukan lagi tempat untuk mengadu bagi anak, maka anak mencari jalan keluar dengan cara bertentangan dengan aturan atau normanorma dalam masyarakat.

Faktor lingkungan sosial, disebabkan oleh:

a) Pengaruh teman sebaya.

Teman mereka atau satu kelompok, dapat memberi pengaruh yang kuat, terutama bagi para remaja.Bila dia berteman dengan pemakai narkotika atau pengedar, tentu dia berusaha membujuk anggota kelompoknya untuk memakai barang terlarang tersebut.

b) Faktor diri sendiri.

a. Kurang menghayati nilai-nilai agama.

Agama sudah mengatur manusia untuk bertingkah laku yang baik dan menghindari tingkahlaku yang buruk dan menjauh setiap larangan yang bertentangan dengan agama. selain itu disebabkan juga karena lemahnya iman seseorang sehingga orang tersebut bisa terjerumus pada penyalahgunaan narkotika.

b. Pribadi yang muda kecewa, sedih dan cemas.

Orang demikian tentu berusaha untuk mengatasi masalah yang sedang dihadapi atau dialami tetapi karena perasaannya dalam keadaan labil maka bila ada tawaran biasanya cenderung diterima tanpa berfikir secara rasional. Tipe-tipe orang seperti ini mudah 
digiring dalam penyalahgunaan narkotika

c. Individu mempunyai keinginan untuk mencoba-coba.

Ada individu yang mempunyai keinginan yang besar untuk mencobacoba terutama para remaja, karena pada masa tersebut mereka masih labil. Adanya godaan dari pihak luar individu yang bersangkutan cenderung untuk narkotika.

\section{Tindakan Sosisal}

Tindakan sosial suatu perbuatan, perilaku atau aktivitas untuk mencapai tujuan subjektif dirinya. Tindakan sosial dilakukan oleh individu, kelompok atau masyarakat yang bisa atau mampu mengarahkan kepada individu, kelompok lain mampu mempengaruhinya.Pokok persoalan weber sebagai pengemuka exemplar dari paradigma ini mengartikan sosiologi sebagai studi tentang tindakan sosial antar hubungan sosial. Namun Emile Durkheim juga berpendapat bahwa tindakan sosial adalah sebagai perilaku manusia yang diarahkan ke norma-norma dan solidaritas kelompok tempat ia hidup.

\section{Narkotika}

Menurut Undang-Undang RI Nomor 35 Tahun 2009 Tentang Narkoba pada bab I pasal I, Narkotika adalah zat atau obat yang berasal dari tanaman atau bukan tanaman, baik sintesis maupun semisintesis, yang dapat menyebabkan penurunan atau perubahan kesadaran, hilangnya rasa nyeri dan dapat menimbulkan ketergantungan.

Narkoba merupakan akronim dari narkotika, psikotropika dan zat adiktif lainnya (Napza), secara umum narkoba adalah zat-zat kimiawi yang apabila dimasukkan kedalam tubuh baik secara oral (diminum, dihisap, dihirup dan disedot) maupun disuntik, dapat menimbulkan gangguan keadaan sosial yang ditandai dengan indikasi negatif, waktu pemakaian yang panjang dan pemakaian yang berlebihan.

\section{Remaja}

Remaja adalah masa peralihan dari masa anak-anak ke masa dewasa, meliputu, semua perkembangan yang dialami sebagai persiapan memasuki masa dewasa. Kemudian Remaja juga merupakan salah satu unsur generasi muda, mengingat umur mereka masih belasanm tahun. Dalam kurun terakhir ini, muncul kecemasan dikalangan masyarakat tentang perilaku laku remaja yang cenderung mengarah kepada perbuatan melanggar norma-norma sosial dan normanorma agama serta aturan-aturan hukum (Dalam, Akma, 2018 ).

$$
\text { Proses terjadinya }
$$

penyalahgunaan narkotika dikalangan remaja, mulai dari adanya interaksi sosial karena dimana interaksi ini memiliki hubungan timbal balik antara individu dengan kelompok. Dengan adanya pernyataan tersebut menunjukan bahwa interaksi sosial tidak mungkin terjadi apabila manusia mengadakan hubungan dengan sesuatu sama sekali tidak memberikan pengaruh kepada system syarafnya sebagai akibat hubungan tersebut.

\section{Teori Tindakan Sosial Max Weber}

Menurut Max Weber Tindakan sosial adalah suatu tindakan individu sepanjang tindakan itu mempunyai makna atau arti subyektif bagi dirinya dan diarahkan kepada tindakan orang lain. Sebaliknya suatu tindakan individu yang diarahkan kepada benda mati berarti tindakan itu tidak termasuk dalam kategori tindakan sosial.suatu tindakan akan dikatakan tindakan sosial ketika tindakan tersebut benar-benar diarahkan kepada orang lain.

Pokok persoalan weber sebagai pengemuka exemplar dari paradigm ini mengartikan sosiologi sebagai studi tentang tindakan sosial antar hubungan sosial. Inti tesis adalah tindakan yang penuh arti dari 
individu. Yang dimaksudkan dengan tindakan sosial itu adalah tindakan individu sepanjang tindakannya itu mempunyai makna atau arti subjektif bagi dirinya dan diarahkan kepada tindakan orang lain.

Penelitian sosiologi harus menginterpretasikan tindakan aktor, dalam arti yang mendasar, seorang peneliti harus mampu memahami motif dari tindakan sosial.Atas dasar rasionalitas tindakan sosial. Menurut Max Weber, tindakan dapat digolongkan menjadi tiga kelompok tipe untuk menjelaskan makna tindakan yang berbeda dalam konteks motif para pelakunya, yaitu tindakan rasionalitas instrumental, tindakan afektif dan tindakan tradisional.

a) Tindakan Rasionalitas Instrumental.

Menurut Weber tindakan rasionalitas instrumental yaitu tindakan yang ditentukan oleh harapan terhadap perilaku objek dalam lingkungan dan perilaku manusia lain, harapan-harapan ini digunakan sebagai syarat atau sarana untuk mencapai tujuan aktor lewat upaya dan perhitungan rasional terhadap dirinya untuk bertindak (Dalam Citra ,2019).

b) Tindakan Afektif

Tindakan ini sebagian besar dikuasai oleh perasaan atau emosi tanpa pertimbangan yang secara intelektualitas. Tindakan inin dilakukan tanpa ada kesadaran pada dirinya, individu melakukan tindakan sosial tanpa dia berfikir apakah tindakan itu baik atau buruk.Jadi dapat dikatakan tindakan ini dilakukan atas persahabatan dari teman bergaulnya, sehingga individu ini ikut-ikutan dalam melakukan mengkonsumsi narkotika, pada akhirnya dia bertindak dan melakukan halhal yang negatif dalam lingkungan sosial.

c) Tindakan Tradisional

Tindakan yang didasarkan atas kebiasaan-kebiasaan dalam mengerjakan sesuatu masa lalu.Tindakan tipe ini merupakan tindakan sosial yang bukan rasional kalau seorang individu memperlihatkan perilaku karena kebiasaan, tanpa refleksi yang sadar atas perencanaan. Perilaku seperti itu dapat digolongkan sebagai tindakan tradisional. Individu itu akan membenarkan atau menjelaskan tindakan itu kalau diminta dengan hanya mengatakan bahwa dia selalu bertindak dengan cara seperti itu atau perilaku seperti itu merupakan kebiasaan baginya

\section{METODE PENELITIAN}

\section{Waktu dan Lokasi Penelitian}

a. Waktu

Penelitian" Perilaku sosial pengguna narkotika dikalangan remaja kabupaten bima, penelitian dilaksanakan pada bulan Oktober 2020. Waktu yang digunakan selama satu bulan dimulai dari persiapan, penentuan informan, penyusunan pedoman wawancara, wawancara mendalam hingga olah data hasil penelitian.penelitian ini diselesaikan dengan memperhatikan validitas data yang diperoleh.

b. Lokasi

Penelitian ini berlangsung di Desa Payi, Kecamatan Wera, Kabupaten Bima, dengan pertimbangan bahwa lokasi tersebut menjadi salah satu Desa dengan pengguna narkotika diusia remaja yang lumayan besar,remaja pengguna narkotika ,keluarga dan masyarakat telah memberikan informasi secara lengkap serta dapat dipertanggungjawabkan kebenarannya.

\section{Tipe dan Dasar Penelitian}

a. Tipe penelitian

Penelitian ini menggunakan tipe penelitian Deskriptif Kualitatif yang mampu memberikan gambaran umum tentang perilaku sosial pengguna narkotika dikalangan remaja.Sesuai dengan tema permasalahan yang diangkat, deskriptif kualitatif dianggap cocok karena perlunya penggambaran perilaku remaja.

b. Dasar Penelitian 
Jurnal Ilmu Sosial dan Pendidikan

http://ejournal.mandalanursa.org/index.php/JISIP/index

Terakreditasi Peringkat 5 (No. SK:

85/M/KPT/2020)

Dasar penelitian yang digunakan dalam penelitian ini adalah Studi Kasus Perilaku sosial remaja pengguna narkotika, Desa Payi, yaitu penelitian yang melihat obyek penelitian sebagai kesatuan integrasi, yang penelaahannya kepada satu kasus dan dilakukan secara intensif, mendalam, mendetail, dan komprehensif.

\section{Teknik Penentuan Informan}

Cara yang digunakan untuk menentukan informan dalam penelitian iniyaitu teknik purposive sampling dan Snowball sampling. Penelitian ini mengambil informan berdasarkan maksud dan tujuan penelitian. Adapun kriteria informan yang ditunjuk atau dipilih dalam penelitian ini adalah remaja pengguna narkotika, keluarga dan Tokoh masyarakat. Kriteria-kriteria dalam penelitian ini antara lain :

1. Mereka berdomisili di Desa Payi

2. Remaja Pengguna Narkotika

3. Keluarganya

4. Mantan pengguna narkotika

5. Tokoh masyarakat

6. Polisi

7. $\mathrm{BNN}$

Berdasarkan Kriteria tersebut peneliti memilih Sepuluh (10) informan. Dari sembilan informan tersebut beberapa informan ditentukan dengan teknik purposif sampling, yang memang telah ditunjuk oleh peneliti sebagai informan, dan informan lainnya ditentukan menggunakan teknik snowball sampling dengan mencari tau kriteria informan melalui adik peneliti serta informan yang telah di wawancarai sebelummnya. Pemilihan sepuluh (10) informan tersebut didasarkan pada peneliti yang menganggap jumlah tersebut telah mampu menjawab pertanyaan-pertanyaan dari penelitian. Pada penentuan informan ini peneliti tidak merujuk pada jenis kelamin, tetapi peneliti menentukan usia dari informan yaitu 14-18 sampai 21 tahun. Merujuk pada krakteristik diatas jumlah informan sepuluh (10) orang,.

\section{Teknik Pengumpulan Data}

Vol. 5. No. 1 Januari 2021

p-ISSN: 2598-9944 e-ISSN: 2656-6753
Teknik pengumpulan data dalam penelitian ini diperoleh melalui cara-cara, sebagai berikut:

1. Data Primer

Data primer, yaitu data yang secara langsung diperoleh dari sumbernya, melalui observasi, wawancara mendalam.Berikut teknik pengumpulan data yang dilakukan oleh penelitian untuk memperoleh data

a) Wawancara Mendalam

Wawancara mendalam adalah bentuk komunikasi langsung antara peneliti dan informan.Komunikasi berlangsung dalam bentuk Tanya-jawab dalam hubungan tatap muka, sehingga gerak dan mimik responden merupakan pola media yang melengkapi katakata secara verbal.wawancara mendalam ini berusaha menggali informasi dari informasi dari informal dengan mengajukan pertanyaanpertanyaan yang terkait dengan penelitian tentang perilaku sosial pengguna narkotika dikalangan remaja.

b) Observasi

Observasi adalah alat pengumpulan data melalui pengamatan secara sistematis tentang gejala-gejala atau peristiwa yang diselidiki. Dalam hal ini, observasi dilakukan oleh peneliti secara langsung mengamati berbagai aspek kehidupan masyarakat dan lingkungannya di antaranya kondisi lokasi penelitian secara umum, kondisi tempat tinggal pengguna narkotika dan juga lingkungan sosial, serta berbagai peristiwa yang terjadi berkaitan dengan permasalahan.

2. Data Sekunder

Data ini berupa dokumen-dokumen yang dibutuhkan dalam menunjang hasil penelitian data sekunder yang digunakan pada penelitian ini berupa dokumentasi.

\section{HASIL PENELITIAN}

\section{Gambaran perilaku social pengguna narkotika dikalangan remaja.}

perilaku sosial adalah suatu tindakan yang dilakukan oleh seseorang dengan cara 
memberikan makna secara subjektif pada dirinya, kemudian tindakan itu mempengaruhi atau menganggu orang lain. Perubahan kondisi lingkungan social masyarakat akibaat adanya perilaku yang tidak sesuai dengan norma-norma adat istiadat yang berlaku di tengah kehidupan masyarakat, karena dimana akhir-akhir ini sering terjadi keributan, perkelahian , pencurian,penjabretan yang terjadi lingkungan masyarakat.

Kemudian yang perlu kita mengetahuinya bahwa narkotika atau Napza adalah suatu zat kimia yang apabila dimasukan ke dalam tubuh kita, dapat mempengaruhi pikiran, suasana hati yang tenang, dan perilaku seseorang. Hal ini dapat menimbulkan gangguan psikologis dan juga akan menimbulkan gangguan keadaan sosial yang negatif,akibat perilaku dan perbuatan mereka. Dalam mengkonsumsi narkotika akan mempengaruhi pikiran seseorang untuk melakukan hal-hal sesuai dengan keinginan hatinya karena menurut dia positif, akan tetapi dilain sisi perilaku dan perbuatan bisa merugikan orang banyak, dan juga kalau orang yang memakai narkotika kalau sudah ketagihan oarng itu akan stress, sehingga untuk mendapatkan barang tersebut mereka akan melakukan berbagai macam cara seperti mencuri, menipu.

Kalau dilihat dari penjelasan di atas terkait dengan realitas yang terjadi sekarang, akibat pengaruh narkotika yang mereka konsumsi, telah mempengaruhi perubahan perilaku seseorang untuk mengarah ke hal-hal yang negatif dan pernyataan di atas sesuai yang kami temukan dilapangan, berdasarkan hasil wawancara kemarin dengan salah satu tokoh masyarakat yang ada di desa payi, kabupaten bima yang menjelaskan yaitu :

"Akhir-akhir ini perilaku remaja yang terjadi sekarang dilingkungan masyarakat, sangat menghawatirkan karena anak-anak disini sering berkelahi, namun masalah yang paling parah, masyarakat sering kehilangan yang mereka punya di ambil sama orang lain. Bahkan yang terjadi sekarang ada beberapa orang yang menjadi gila akibat terlalu banyak mereka mengkonsumsi barang tersebut. Perilaku atau perbuatan mereka ini sudah mengganggu orang lain."(BHR, Kamis 4 November 2020 pukul 15 : 25).

Dari informan (BHR) mengungkapkan kondisi sosial akibat penyalahgunaan narkotika membawa dampak yang buruk bagi lingkungan masyarakat dan lebih-lebih dapat menghancurkan masa depan anak bangsa. Maka hasil wawancara di atas dapat kita simpulkan bahwa perilaku remaja yang ada di desa payi, kabupaten bima, telah mengganggu dan merugikan masyarakat setempat dan juga dapat merugikan dirinya sendiri.

Terjadinya perubahan di dalam lingkungan sosial sekang di lihat dari realitas yang terjadi sekarang, yang dilakukan oleh remaja, telah memberikan efek yang negatif bagi masyarakat dan juga remaja yang lain yang ada di lingkungan tersebut. maka hal ini kalau di biarkan terus menerus dapat merusak moralitas remaja yang tinggal dilingkungan tersebut. Kemudian berdasarkan pendapat kepala dusun payi dalam, yang tinggal disitu yang kita wawancara kemarin terkait dengan perilaku remaja yang ada di wilayah tersebut.

"Kondisi sosial yang terjadi didalam kehidupan masyarakat saat ini, yang di akibatkan tindakan yang mereka lakukan.Bahwa perbuatan remajayang dilakukan suda melanggar norma-norma dan adat istiadat yang berlaku di tengah kehidupan masyarakat. Akhir-akhir ini masyarakat sering kehilangan kambing dan juga ayam mereka yang di curi sama rekanrekan muda yang ada lingkungan tersebut." (MNS, Sabtu 08 November 2020 pukul 17:15).

Hasil pendapat kepala dusun payi dalam diatas dapat kita simpulkan, bahwa perbuatan yang mereka lakukan ini sudah melanggar norma-norma dan adat istiadat yang berlaku 
Jurnal Ilmu Sosial dan Pendidikan

http://ejournal.mandalanursa.org/index.php/JISIP/index

Terakreditasi Peringkat 5 (No. SK:

85/M/KPT/2020)

dimasyarakat.Kemudian pemerintah setempat telah melakukan upaya untuk menguranngi perilaku remaja pengguna narkotika biar mereka tidak mengulangi perbuatannya, sehingga ada efek jeratnya bagi remaja yang melakukan perbuatan tersebut.

Realitas sosial yang terjadi saat ini kalau dilihat dari beberapa pernyataan yang di jelaskan oleh beberapa informana,terkait dengan perilaku remaja. Kalau kita melihat tindakan ini dengan menggunakan Teori Tindakan sosial Max Weber, sangat jelas sekalai. Menurut Max Weber bahwa Tindakan Sosial merupakan suatu tindakan atau perilaku individu yang sepanjang tindakan itu mempunyai makna secara subyektif bagi dirinya dan diarahkan kepada orang lain. Artinya tindakan sosial itu memberikan makna untuk dirinya dan kemudian tindakan itu mengganggu dan merugikan orang lain. Kalau kita lihat tindakan sosial yang terjadi sekarang yang ada di desa payi, kabupaten bima, termasuk tipe tindakan sosial afektif, sesuwai yang di jelaskan oleh Max Weber. Karena dimana tindakan sosial secara afektif adalah tindakan ini sebagian besar dikuasai oleh perasaan atau emosi tanpa pertimbangan yang secara intelektualitas.

Tindakan dilakukan tanpa ada kesadaran pada dirinya, individu melakukan tindakan sosial tanpa dia berfikir apakah tindakan itu baik atau buruk. Jadi dapat dikatakan tindakan ini dilakukan atas persahabatan dari teman bergaulnya, sehingga individu ini ikut-ikutan dalam melakukan mengkonsumsi narkotika, pada akhirnya dia bertindak dan melakukan halhal yang negatif dalam lingkungan sosial.

\section{Kesimpulan}

Berdasarkan hasil penelitian yang telah dilakukan terkait" Perilaku Sosial Pengguna Narkotika Dikalangan Remaja Desa Payi Kabupaten Bima"maka kesimpulannya yaitu :

1. Gambaran perilaku sosial pengguna narkotika dikalangan remaja. Dapat kita simpulkan bahwa penyalahgunaan narkotika
Vol. 5. No. 1 Januari 2021

p-ISSN: 2598-9944 e-ISSN: 2656-6753 dapat menimbulkan perilaku yang menyimpan masyarakat, karena mereka telah melakukan tindakan, pencurian, penipuan dan perkelahian dan juga kejahatan lainya. Secara jelas tindakan ini dapat mengganggu orang lain.

2. Pengaruh perilaku remaja terhadap keluarganya dan juga masyarakat. Dengan adanya perilaku remaja seperti sekarang telah memberikan pengaruh yang negatif terhadap keluarganya dan juga masyarakat yang tinggal dalam lingkungan sosial tersebut. Karena tindakan merekan lakukan dapat merusak moralitas remaja yang lain.

\section{Saran}

Melihat hasil penelitian di lapangan sesuwai dengan realitas sosial yang terjadi ada beberapa hal yang perlu dilakukan oleh masyarakat, keluarga dan aparat pemerintah dan juga kerjasama dengan aparat kepolisian sebagai berikut :

1. Diharapkan perlu ada kerjasama antara aparat kepolisian dengan pemerintah Desa.untuk mencegah masuknya narkotika khususnya di desa payi, kecamatan wera, karena hal dapat merusak moralitas regenerasi masa depan bangsa.

2. Lingkungan keluarga, lingkungan sosial dan pemerintah dan juga agama sangat berperan penting untuk menjadi perhatian dalam pengambilan peran untuk memberikan pendidikan yang baik, sosialisasi dan selalu mengontrol anak-anaknya agar mereka terhindar dalam penyalahgunaan narkotika. Karena narkoba dapat menjadikan seseorang sakaw (ketagihan), sekali mencoba tidak bisa terlepas dari jeratan dan lilitan narkoba, kecuali kesadaran diri dalam lubuk hati si pengguna untuk berhenti menggunakan narkotika.

\section{Daftar Pustaka}

Adyani,(2018), Peran Masyarakat Dalam Menanggani kenakalan remaja,Skripsi. Banda Aceh,Universitas Islam Negeri Ar-Raniry. 
Jurnal Ilmu Sosial dan Pendidikan

http://ejournal.mandalanursa.org/index.php/JISIP/index

Terakreditasi Peringkat 5 (No. SK:

85/M/KPT/2020)

Hantoro dan Aziz,(2008) Ilmu Sosial Dasar, (Jakarta: Bumi Aksara, hlm. 88.

Hawi, (2018), Remaja Pecandu Narkoba pondok pesantren Ar- Rahman Palembang. UIN Raden Fatah Palembang,Hal 103.Jurnal.

Hidayat, (2016), dampak sosial penyalahgunaan narkoba pada remajadi kelurahan kalabbirang kecamatanpattallassang kabupaten takalar.Jurnal, uin alauddin makassar. Jurnal

http://kahaba.net/berita-bima/73443/didugapengedar-sabu-sabu2-warga-wera-paidibekuk-polisi.html.Di akses pada tanggl 20 oktober 2020.

http://sekolahsosial.blogspot.com..pengertiantindakan-sosial-menurut-para.html, Di Akses pada tgl 18 oktober 2020 .

http://webcache.googleusercontent.com/search? $\mathrm{q}=$ cache:tUlfmxlRMZgJ:materipelajara nterbaruips.blogspot.com/2016/10/bent uk-bentuk-tindakan-sosial.Di kutip pada tgl 17-10-2020.

http://www.mediantb.com/2018/11/edarkannarkoba-jenis-sabu-polsekwera.html.Di akses pada tgl 20 oktober 2020.

https:// dendibatinova.wordpress. com /2020/10/06/jam :11:25perilaku-siosial.

https://www.seputarpengetahuan.co.id.pengertia n-tindakan sosia Di akses pada tgl 16 oktober 2020.

Khairulazharsaragih, $\quad(2020, \quad 07$ oktober),tindakan sosial Weber. Diakses pada 28 januari 2014, dari http://khairulazharsaragih.blogspot.co m/tindakan-sosial-menurut-maxweber.html

M.Masjkur, (2016), Penyalahgunaan Narkoba Di Kalangan Remaja Dalam Perspektif Islam.IAI Sunan Giri Bojonegoro.Jurnal

Makarnao,(2003) dkk, Tindak Pidana Narkotika, (Jakarta, Ghalia Indonesia, hal 54.
Vol. 5. No. 1 Januari 2021

p-ISSN: 2598-9944 e-ISSN: 2656-6753
Maswari M Adnan,(2015) Memahami Bahaya Narkoba dan Alternatif Penyembuhannya, (Pontianak, Media Akademihal 8.

Melati (2014 )perilaku sosial remaja putri penyalah guna narkoba di perumahan btn manggar balikpapan timur.

Radhiah, (2013) Analisis perilaku sosial pengguna narkoba pada remaja di kotaMakassar,.

Ritzer(2001).Sosiologi Ilmu Berparadigma Ganda.(Jakarta PT Rajawali Press., 126

Setiyawati, (2015), dkk, Buku Seri Bahaya Narkoba Jilid 1, (Surakarta, Tirta Asih Jaya, hal 153.

Simangunsong,(2015), Penyalahgunaan narkoba dikalangan remaja (Studi kasus pada badan Narkotika nasional Kota Tanjungpinang)Universitas Maritim Raja Ali Haji Tanjungpinang.

Soekanto (2002), Sosiologi Suatu Pengantar.Jakarta : $\quad$ Raja Persada,hal.43

Sugiyono. 2014. Metode Penelitain Kuantitatif, Kualitatif, dan $R \& D$. Bandung: alfabeta, CV.

suhadi, (2014) perilaku sosial pengguna narkoba(studi kasus kelurahan simpang tiga kecamatan kaur utarakabupaten kaur.

Suryani, (2018), Dampak penyalahgunaan narkoba terhadap perilaku remaja diKecamatan rantau utara kabupaten labuhanbatu.Stkip yayasan universitas labuhanbatu.

Yunus (2016), Pembina perilaku sosial remaja penghuni yayasan islam media kasih kota banda aceh. Universitas Syiah Kuala. 